\title{
Language, culture and interculturality through narratives with learners of Spanish as a foreign language
}

\author{
Amparo Rodrigo-Mateu \\ Universitat de València
}

(Text received June 06 2018; accepted September 03 2018; final version December 18 2018)

DOI: https://doi.org/10.5565/rev/jtl3.761

\begin{abstract}
This research focuses on a classroom experience with adult learners of Spanish as a foreign language. The aim is to delve into the joint development of linguistic, communicative and intercultural competences through writing. We will observe the communicative competence from an intercultural perspective in a language learning process based on sociocultural reflections.

The work is framed within the TALIS Project ${ }^{1}$ (Teaching and Acquisition of Solidarity and Intercultural Competences through Languages and Literature). The result is a published book of twelve bilingual tales (Spanish-English) focusing on languages and interculturality, written by learners of Spanish at the University of Mumbai, in India. Its publishing and distribution mainly target Spain and India, subsequently exploiting the intercultural side of the work carried out. Analysed data also include direct observation in class and evaluations by students after finishing the project, showing students' involvement in their sociocultural environment and the development of intercultural competences throughout the process.
\end{abstract}

Keywords: intercultural competence, culture, narratives, Spanish as a foreign language, social awareness

Resum: Aquesta investigació es basa en una experiència d'aula amb aprenents adults d'espanyol com a llengua estrangera. L'objectiu és aprofundir en el desenvolupament conjunt de competències lingüístiques, comunicatives $\mathrm{i}$ interculturals mitjançant l'escriptura. S'atendrà la competència comunicativa des d'una perspectiva intercultural, en un procés d'aprenentatge de l'idioma basat en reflexions socioculturals.

El treball queda emmarcat dins el Projecte TALIS (Ensenyament i Adquisició de Competències Solidàries i Interculturals a través de les Llengües i de la Literatura). El resultat ha estat la publicació d'un volum de contes bilingües (espanyol-anglès), amb un enfocament lingüístic i intercultural i redactat per aprenents d'espanyol de la Universitat de Mumbai, a l'Índia. La seua publicació i la seua distribució tenen como a objectius, principalment, Espanya i l'Índia, tot explotant el component intercultural del treball portat a terme. Així mateix, les dades analitzades inclouen observacions directes a l'aula i avaluacions realitzades pels estudiants en finalitzar el projecte. El conjunt ha demostrat la implicació d'aquests en el seu entorn sociocultural i el desenvolupament de competències interculturals al llarg del procés.

Paraules clau: competència intercultural, cultura, narracions, espanyol com a llengua estrangera, consciència social

Resumen: Esta investigación se centra en una experiencia de aula con aprendientes adultos de español como lengua extranjera. El objetivo es profundizar en el desarrollo conjunto de competencias lingüísticas, comunicativas e interculturales a través de la escritura. Se atenderá la competencia comunicativa desde una perspectiva intercultural, dentro de un proceso de aprendizaje del idioma basado en reflexiones socioculturales.

El trabajo se enmarca dentro del Proyecto TALIS (Enseñanza y Adquisición de Competencias Solidarias e Interculturales a través de las Lenguas y la Literatura). El resultado ha sido la publicación de un volumen de cuentos bilingües (español-inglés), con un enfoque lingüístico e intercultural y redactado por aprendientes de español de la Universidad de Mumbai, en India. Su publicación y distribución tienen como objetivos, principalmente, España e India, con la consiguiente explotación del componente intercultural del trabajo realizado. Los datos analizados incluyen también observaciones directas en el aula y evaluaciones realizadas por los estudiantes al finalizar el proyecto. Todo ello ha demostrado la implicación de estos en su entorno sociocultural y el desarrollo de competencias interculturales a lo largo del proceso. 
Palabras clave: competencia intercultural, cultura, narraciones, español como lengua extranjera (ELE), conciencia social

\section{Introduction}

According to Porto et al. (2017, p. 5), intercultural speakers are capable of understanding how texts can be interpreted by receivers beyond the original contexts. Following this idea, our study presents and analyses a writing activity with students of Spanish as a Foreign Language (hereafter, SFL) at the University of Mumbai, in India. Its final result, which focuses on learning through an intercultural approach, is the publication of the bilingual book of tales (Spanish-English) Mucho más que ríos de vida y fuertes de leyenda... Cuentos de India / Much more than rivers of life and legendary forts... Tales from India (Rodrigo-Mateu, 2017).

Work at the University of Mumbai was conducted in the context of the Spanish Government Assistantships Programme ${ }^{2}$. The activity in its whole is part of the TALIS Project, set up by the University of Valencia, in Spain. TALIS is an innovative educational project offering a platform to foster education for development through culture. Authentic, intercultural and multilingual tales are created in writing workshops by students of different nationalities, presenting their culture, diversity and values focusing on human rights, i.e., equality, diversity, education for development, health and environment. In this context, foreign languages, together with the cultures where they are embedded, are used to work literary, intercultural and communicative competences (Haba Osca, Alcantud Díaz and Peredo Hernández, 2015, pp. 102-103). This applies not only to the initial writing process, but also to further uses of the published tales with a wider audience.

The experience finds also a solid basis on the Common European Framework of Reference for Languages (Council of Europe, 2001) (hereafter, CEFRL) and how it sees learners as social agents. Acts of speech occur within language activities that are part of a wider social context, which, in itself, is able to give them their full meaning. It is in these meaningful contexts where foreign languages act as vehicles of communication in process-oriented approaches (Ruiz-Cecilia, 2012, pp. 225-226). In what follows, and in the terms proposed by the CEFRL, we present a practical and action-oriented case study.

Additionally, Riutort Cánovas \& Pérez Villafañe (2013) point that, in order to achieve communicative competence in teaching-learning processes, existing metholologies need to be adapted to learners' culture. According to this view, if we consider that development of work in class, as well as results, depend on the specific context and cultural conjunctions, new approaches to teaching foreign languages that attempt to be adopted outside Europe should be observed from the 
viewpoint of the new hosting culture and adapted to it. Hence, some key notions associated with culture and interculturality will be discussed in this article.

\section{Research justification}

On the basis of the previous introductory overview, our study finds justification and contextualisation in the following four premises:

First, it is an experience documented and published in book format and in collaboration with the University of Valencia. It entailed networking between two universities placed in different continents and cultures and, all in all, an enormous exchange potential was there to be seized and exploited. Added to this, work was done in south-east Asia, where studies of SFL are in high demand ${ }^{3}$.

Second, the project addresses the writing practice not only from a linguistic approach, but also from an intercultural one, while offering many possibilities of further exploration within the context of plurilingual, intercultural and pluricultural models of language competences (Council of Europe, 2018).

Third, and related to the creative process, learners reflected upon their social environment (Byran \& Fleming, 2009, pp. 13-14) in a foreign language that they were still learning, and they looked for ways to tell their stories in that language. In parallel, prospective readers from other cultures were kept in mind and this means that intercultural awareness was fostered and applied. This study aims to provide real evidence about the positive aspects of intercultural reflection in the foreign language class.

Lastly, it was carried out within the TALIS Project and this provided a framework of reference and a platform to share learning outcomes from different related experiences. Each one of these experiences shows the idiosyncrasy of the place where it was implemented and, at the same time, each one is also determined by its specific learning situation. In this sense, our research is intended to contribute to the growing body of literature published by TALIS, on the basis of the work done in an Indian state university, the University of Mumbai, and in the SFL class. Its publishing and distribution will open new areas for reflection, debate and exchange within the academic and research community. 


\section{Theoretical framework}

"Storytelling is something that is very natural to human beings". This is the introductory line by Indian mythologist Devdutt Pattanaik in his work Culture: 50 Insights from Mythology (2017, pp. 1-2). In his words, we are all storytellers and those who write them are perhaps better storytellers because their stories reach a larger number of people.

According to Hall $(2005$, p. 73$)$ narratives or stories are found in every culture. They are a uniquely human way of understanding the world through the recounting of a sequence of events told from a particular point of view. In spite of the emic differences, narratives at the etic level are essentially actions taken by characters in relation to a problem that is addressed and the perceived outcome or consequences of those actions. Regarding authors and audience, the same story sounds different when the storyteller is different, and every storyteller changes his narration depending on the audience (Pattanaik, 2017).

Parallel to the entertaining side of storytelling, some professionals and scholars work actively and comprehensively on the transformation of both individual and collective consciousness through storytelling (Vevaina, n.d.). They attempt to develop the following literacies:

Psycholiteracy: Awareness of the way in which humans think and feel.

Socioliteracy: Awareness of intercultural differences and the need to respect one another, in order to create a more socially fair world.

Ecoliteracy: Awareness of our connection with the planet and, as a result, the need for deep respect for our natural environment and ecological conservation.

Different aspects related to these three literacies will be discussed in the analysis.

When referring to culture, this is a dynamic entity (Trujillo Sáez, 2002, p. 107) and it can be understood as an outcome of any human interaction (Jin \& Cortazzi, 2009; Pattanaik, 2017). Learning our culture(s), therefore, helps us to coordinate our actions with others' actions and gives meaning to our lives (Hall, 2005, pp. 66-67).

Pande, in his foreword to Saran (1998, p. XXIII), criticises explanations about preliterate cultures being formed by the need and pressures of seeking security and satisfaction through environmental adaptation and social cohesion. From his point of view, this means considering technology and power-based institutionalisations as rational devices, whereas religion, myths and rituals would be of a more irrational nature. Pattanaik (2017, p. 104) also questions whether the concept of culture in India can be separated from certain practices, such as religion.

Language reflects culture. At the same time, language is a part of culture and it also constitutes culture (Jin \& Cortazzi, 2009, p. 105). When talking about language we are referring to a 
whole system of social actions implying cultural meanings. The way we interpret reality responds to the existence of a hidden cultural grammar. Lack of knowledge about this cultural grammar leads to what is known as cross-cultural misunderstandings. As a result, it follows that language cannot be separated from culture (Guillén Díaz, 2016, p. 229).

From a learning perspective, narratives teach us how the world works, our place in it (personal and social identity), how to act (both effectively and appropriately in specific contexts and societies), and how to evaluate or judge what goes on in the world (in terms of what is good/bad and safe/dangerous) (Hall, 2005, pp. 74-75). A variety of factors determine the way different cultures perceive the world (Jian, 2013, p. 203). Realities are facts observed through our senses and frames of reference, and stories construct our truths (Pattanaik, 2017), depending on the cultural system in which we are embedded (Ruiz-Cecilia, 2012, p. 233). Against this background, "stories can be a means of personal and social exploration and reflection -an imaginative vehicle for questioning, shaping, responding, and participating in the world" (McGinley et al., 1997, in Ruiz-Cecilia, 2012, p. 229). However, Neelakantan (2012, p. 2) argues that, far from believing that there are only marked differences between cultures, there also exist parallels, and that this applies, for example, when comparing Indian and European folklore. He refers to belief in charms, in lucky and unlucky days and animals, and fear of curses as common aspects to both cultures.

As to interculturality, the CEFRL takes into account both linguistic and general competences (not specific to language but which are called upon for actions including language activities) in the development of the overall communicative competence in language learners. Although general competences are not specifically language-related, they are considered relevant in language activities (Gutiérrez Rivilla, 2016, p. 23). One of these competences is intercultural awareness (Council of Europe, 2001, ch. 5).

Following the CFERL, through intercultural awareness we establish relations among cultures and observe similarities and differences that help us understand better those relations. At the same time, it means an awareness of how each community is perceived by others. General competences play an important role in language learning when this is understood as intercultural contact, since individuals use their own references and life experiences to decode and understand messages. Sociocultural approaches emphasise that knowledge is built from an $I$ related to the others. This leads us to the concept of interculturality (Guillén Díaz, 2004, pp. 239-241). This encounter with the otherness requires questioning and it can open pathways towards a critical cultural awareness (Byran \& Fleming 2009, p. 14). Trujillo Sáez defines interculturality as a critical 
participation in communication. In his opinion, "interculturality would not be complete if we were not to refer to critical thinking" (Trujillo Sáez, 2002, pp. 107-115).

When talking about cultural learning through narratives, we must be able to see in stories some point of connection to our own lives. We will find some narratives that strike us as more insightful or true to the way the world is than others. This relates to our effort at learning about different cultures through narratives (Hall, 2005, pp. 83-84).

If considering the foreign language class as an intercultural exchange between native teachers and hosting students, an intercultural language teaching approach does not require the teacher to possess comprehensive knowledge of the target culture. It is through exploration, rather than transmission of preordained content, that both teachers and students alike gain knowledge. In addition, considering that language and culture are routinely integrated, existing resources can be used to facilitate this cultural exploration and reflection. The individual's own background is, therefore, a valuable resource for intercultural learning (adapted from Oranje and Smith, 2017, p. 17). Following this, as Ruiz-Cecilia (2012, p. 238) stated in his research, other cultures become enriching sources of knowledge.

\section{Method}

The project was conducted by regular attendants from three groups of students at the University of Mumbai, all of them of Indian origin and speakers of English and Hindi, as well as Marathi (language spoken in Bombay). Their level of Spanish according to the CEFRL was B1, and they were aged between 20 and 67. This age range is explained by the composition of the groups. Two of them were formed by a combination of Bachelor students of French and external students, and one group had only external students. The total sample was formed by 9 Bachelor students of French and 11 external students of different backgrounds, i.e., retired engineers, housewives, business men, literature and commerce graduates, and language teachers.

A total of 20 students (14 females and 6 males) participated in the three group tales and 9 of them (8 Bachelor students of French and 1 external student) wrote, immediately afterwards, their individual stories. 

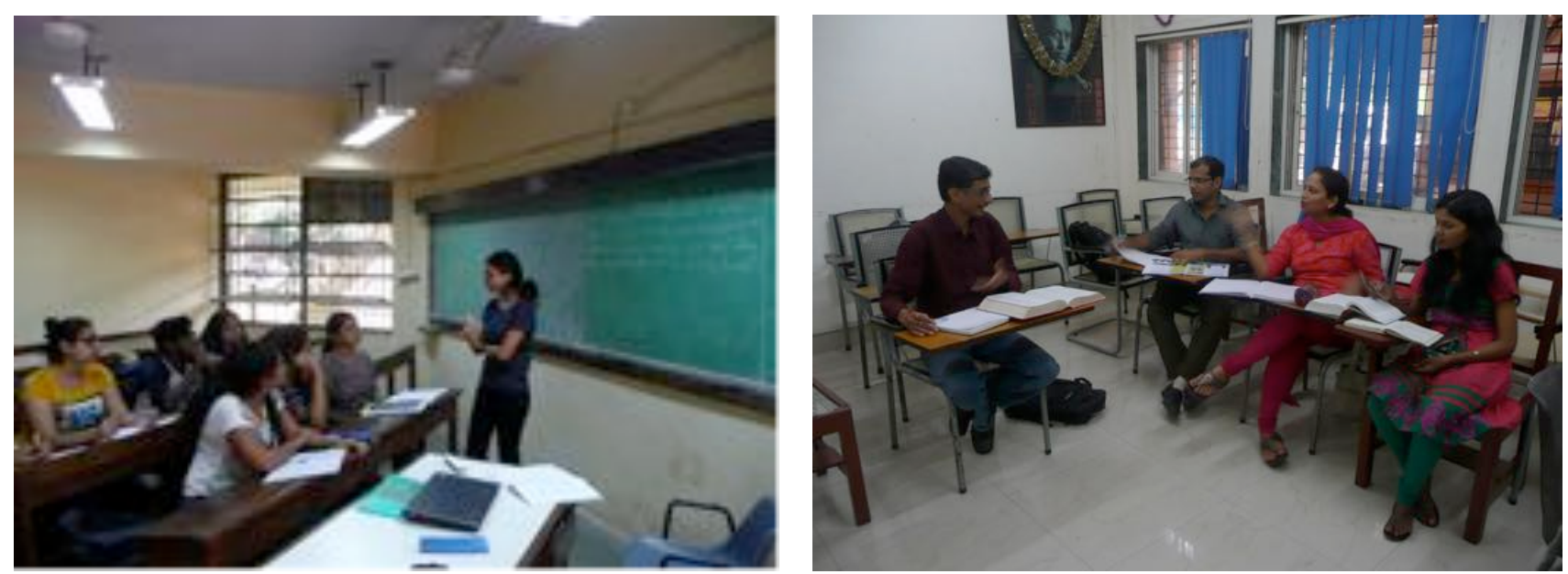

Images 1 and 2. Writing group tales in class.

Research was conducted during two academic years (2014-2015 with two groups of students and 2015-2016 with another group). Its procedure was as follows (adapted from Rodrigo-Mateu, 2017):

1. Contextualisation: TALIS Project is presented to students in class.

2. Reference: Students observe an example of bilingual tale (Spanish-English).

3. Group practice: A group tale is written in class. Then, the tale is translated into English.

4. Individual practice: Students write the first version of their individual tale in Spanish outside the class.

5. Monitoring and provision of tools: The teacher reviews the writings and marks them with correction symbols.

6. Reflection and practice: Students use the correction marks to write an improved version of their tales.

7. The teacher reviews and makes the final correction.

8. Students translate their tales into English.

9. Publication.

Creating the stories was a participatory activity of creative work on oral and written skills. Each tale in Spanish goes with its translation into English. Presentation and format allow for parallel readings in both languages. Added to this, the tales are also available in audio and video formats, read by the same authors ${ }^{4}$.

Different work strategies were required in order to express clear contents in the target language and in the mother tongue. An aspect worth highlighting were cultural references necessarily arising when describing actions related to behaviours and daily life. Examples of these 
are superstitions, traditions, rituals, auspicious days, typical meals, celebrations and, encompassing some of them, religion (Diwali ${ }^{5}$, auspicious day ${ }^{6}$, pooja ${ }^{7}$, act of $\operatorname{God}^{8}$ ). In all of these cases, the emic or native point of view makes use of clarifying footnotes for foreign readers who, initially, will try to understand the messages using their own references and life experiences. These notes become a clear intervention by the author in the narrative and it supports information exchange among distant cultures.

Attention needed to be paid to principles guiding the activity (like characters, topics and human rights), in order to make it coherent with the TALIS international project we were participating in. Related to intercultural work in class, guidelines established by TALIS prevailed when it came to determining and judging actions. At this point, it was necessary to explore perceptions of Indian culture in terms of superhuman feats or elites enabling actions and conflict resolutions. Instead of this, more attention was geared toward a sense of citizenship and citizens as influential social agents (Rodrigo-Mateu, 2017, p. 20).

\section{Findings and discussion}

The tales deal with the following topics: environment (4 tales), education ( 2 tales), girls' education ( 2 tales); child labour ( 3 tales); family ( 3 tales); poverty ( 2 tales); animal protection ( 2 tales); ambitions ( 2 tales); health ( 1 tale), and superstitions ( 1 tale). The representativeness of most of the topics is observed in more than one tale.

Actions, characters, problems and results appear clearly depicted in all the tales. All of them were planned beforehand with the students in order to structure subsequent linguistic practice. It should be noted that, while it may be a truism that the way we use language shows our culture and world views, in our case this perception is subject to the limitations of using a foreign language that students were still learning as a vehicle for expression.

Added to the linguistic effort to produce written texts, the project entailed a reflection on how to reach foreign readers when using words in Hindi. They refer to cultural aspects within the Indian society and their meaning cannot be inferred from the context. Some examples are dhoti ${ }^{9}$, gram panchayat ${ }^{10}$ or sarpanch $^{11}$. In this sense, narratives needed to be adapted to the audience, with the help of footnotes, as mentioned earlier. The way stories are told is, therefore, determined by two factors: first, by the author's language limitations as foreign language students and, second, by the existence of a foreign audience that needs to understand terms and cultural aspects from the native context where stories occur. 
Stories are limited in time (present) and place (India). Parallel to development of communicative competences, students reflected on their social context to detect concerns, like the need for environmental protection, the right to education and the importance of gender equality, among others. Accordingly, first, the tales offer a look at Indian society and culture to foreign readers. Second, the whole development of creating them represents a conscious and critical look beyond students' immediate surroundings, depicted also in a series of tales describing actions taking place in cities as well as in rural or isolated areas:

Es un día agradable de noviembre en Bombay, una enorme ciudad que nunca duerme y donde la gente celebra muchas fiestas con entusiasmo.

It is a pleasant November day in Bombay, a big city that never sleeps and where people celebrate many festivals with enthusiasm.

Beginning of the tale Un nido de iluminación / An Englightening Nest

En un año de lluvias torrenciales, el pueblo de Baliganj, en la desembocadura del río Ganges, quedó completamente inundado.

In a year of torrential rains, the village of Baliganj, at the mouth of the river Ganges, was completely inundated.

Beginning of the tale Una decisión inteligente / A Smart Decision

Hace algunos años, en Sunderpur, un pueblo pequeño y tranquilo en el centro de India, vivía una familia de agricultores. A few years ago, in Sunderpur, a tiny and quiet village in the central part of India, lived an agricultural family.

Beginning of the tale ...Y el bosque se salvó / ...And the Forest Was Saved

Overall, the stories helped students to connect with contemporary incidents occurring in their society, enabling them to establish continuity of what they learn with their lives. By sharing concerns and reflecting upon them, they were linked even more to their history and culture. Some of the matters of concern expressed are still deeply rooted in the tradition of the country like, for example, obstacles that women face in rural areas to access education or child labour.

— What happened, dear? Why are you crying?

She replied:

— My father is forcing me to work to help my family, but I want to study. If I work, I will not be able to study. My father will never understand this. Please help me.

Un viaje inolvidable / Un Unforgettable Trip 
Ramprasad had a son, Shyamprasad, who was eight years old and a daughter, Durga, who was six. His wife Shanta was a progressive thinking woman who was very keen to send her daughter to school along with her son. Ramprasad, who was very conventional and afraid of social repercussions, did not agree with Shanta. But she was very persistent and, despite the stiff opposition from her husband, sent her daughter to school.

This shocked the villagers and they began to taunt Ramprasad:

- There goes the fool who will never be able to get a husband for his daughter.

- Who will marry a girl who goes with the boys to school?

- She will bring dishonour to the family.

— She will bring dishonour to our village.

Un nuevo amanecer en Janakpur / A New Dawn in Janakpur

By observing these concerns, students also took a stand on them, i.e., they achieved a critical cultural awareness. "If a storyteller believes that women are victims, their stories will be full of female characters who are subjected to all forms of injustice. Storytellers then become creators of values and judgements" (Pattanaik, 2017, p. 4). In our stories, it was precisely two female students who chose issues affecting women for their individual tales (women and education), and also female students voted for a young girl as the main character in one of the group tales related to education and environmental protection. This shows gender-awareness in an Indian male-ruled society, as well as the authors' view about the influencing role of women in important fields such as education and environment:

The happiest moment was when Durga heard that her mother had been recently elected unanimously as the sarpanch of Janakpur. One single woman's determination and perseverance had brought about that transformation. Tears of joy and pride streamed down her face. Durga hugged her mother. Janakpur had indeed come a long way.

End of the tale Un nuevo amanecer en Janakpur / A New Dawn in Janakpur

Soon all the houses in Sunderpur had gobar gas. Today, with the initiative of Astha, the trees, as well as the animals, are protected.

— Grandma, thank you very much for giving your savings for this project — said Astha-. Without them, it was impossible.

— Beta, my contribution was nothing, but it was your concern what saved the forest of Sunderpur. I am proud of you.

End of the tale ...Y el bosque se salvó / And the Forest Was Saved

Existing resources in students' surroundings and backgrounds were used as sources of knowledge for further exploration and work while learning Spanish. As mentioned above, selecting the topics for the tales brought students through an exercise of awareness-raising and reflection 
upon their own culture. With this, they became more than learners. According to Guillén Díaz (2004, p. 240), they are considered social actors interacting and, as such, they require mental operations to search, discover, analyse, compare, reflect, interpret and describe. By assigning classmates' names to the characters in the stories, mostly in group tales, students show also a high degree of identification and involvement in their narratives.

If we break down this process of awareness-raising, reflection and learning into the three literacies (Vevaina, n.d) intended to be developed in the story-writing process, we find that, overall, the whole method of writing tales enabled students to develop their psycholiteracy, socioliteracy and echoliteracy skills. First, throughout a critical reflection process, they established links among facts, their reasons and their consequences, thus developing empathy for the characters in their stories. Second, they worked their intercultural skills by becoming more aware of how their culture was going to be perceived and understood by foreign readers, and also when working cooperatively in the classroom (diversity among students was found in their ages and backgrounds). Third, environment was the most represented topic, and this entailed work on ecoliteracy skills:

— Yes, yes. It is much better this way. How much do I have to pay? — responds Narayan.

- I do not need anything, saheb. In fact, you have already paid because today you came walking and you have not used your car, you have not polluted the air and you have not contributed negatively to global warming, you have not caused noise and you have done something good for your health, as well. And the joy that your daughter has felt on talking so much with you, it cannot be expressed!

In this way, Narayan saheb has helped not to worsen global warming. In addition to this, he has not polluted the air. And you all, what will you do?

Un paso seguro / A Perfect Footstep

Immediately after finishing the project, students conducted a written evaluation. They were asked to write their reflections in English, so they could express themselves naturally and clearly. In their comments we read about the reasons why they chose their topics, the challenges they faced and what they learnt:

"It wasn't difficult to agree on a topic as pollution for the short group tale, since it's a very serious problem in Mumbai. It is important to make people aware of pollution. We also talked about Diwali, a very important festival celebrated in Mumbai. Our main idea was how to celebrate festivals without causing harm to nature. A group activity helps one to learn how to work together. Team work is very important. Working with many minds we had many opinions and then we came to a conclusion. In spite of disagreeing to some ideas, there was a lot of support and teach work within us. There was a lot of support from our professor as well. It was fun working with all classmates. My individual tale is 
about education. I feel education is a necessity in order to live a better life. Through education one knows the difference between right and wrong. This activity helped me to learn new vocabulary. I really liked the procedure of writing my own short tale. First, I had to think of my background story, then I had to write it in Spanish. This helped me to know my command over the language. After submitting my story my professor corrected it. She only marked out my mistakes. I had to then think over my mistakes. This was a very interesting process. This activity was learning with enjoyment. I'm sure I will write more tales".

Female student

"The tale writing session in group was fun. Along with it, we not only learned to write in Spanish or to practise it but also [...] we had an opportunity to work with our classmates, sharing many different ideas that each one of us had. [...] For the individual tale I reached a topic: pollution. I developed the subject by introducing a 'magic key' along with three people who could help us to know the way to reduce pollution. I faced difficulties, but I remembered the way how we worked systematically in class and everything went with ease. So I carried on in the same manner. Working individually gave me more confidence than before and now I can write any tale with no fear. I would say that one needs encouragement and determination to work on any task”.

Male student

Overall, combining linguistic and cultural contents with social and political issues made students identify themselves also as citizens and as members of their communities, while fostering a comprehensive quality of education. This is revealed in the comments made by students in the video presenting the project ${ }^{12}$.

The twelve tales were created in an Indian university classroom with native Indian students working together with a native Spanish teacher. In this particular context, intercultural exchange in the SFL entailed an interaction among students, who were familiar with the source culture of the stories, and a teacher, who was familiar with the receiving target culture, i.e., future readers of the stories.

As reflected in the above-mentioned presentation video, students' performance was also enhanced by their high motivation to participate in an international project coordinated by the University of Valencia, as well as by the fact of being aware that people from other countries were going to read them, mostly native speakers of the foreign language that they were learning, that is to say, Spanish native speakers.

By stories being published, both in written and audio format, they reached a wider audience. Concerning cultural reflection, this entailed a two-way system. First, learners' culture was considered when selecting topics for writing. Then, in parallel, the results were going to be read by people from other cultures. We are dealing, thus, with a study based on cultural transfer, guided by 
a target audience that students had in mind throughout the writing practice. How texts were going to be decoded by readers in other cultural systems being exposed to different perspectives of the world (Ruiz-Cecilia, 2012, pp. 227-229) was, therefore, part of an intercultural reflection process that aimed at including both, Indian students writing the stories and future readers from other cultures. Examples of aspects used in the stories that give room for intercultural reflection, with their respective footnotes provided by the authors, are as follows:

Local structures for decision-making, like gram panchayat, baithak or sarpanch:

The sarpanch appreciated my efforts and promised that he would visit the village. Following his promise, he arrived at the village and organized a baithak $k^{5}$ In that baithak, he made strict rules. He said that no girl below the age of eighteen should be forced to work. And it was compulsory that all the girls attended school.

(Footnote) ${ }^{5}$ Meeting organised by the sarpanch of the village. In this meeting, important decisions are taken.

Un viaje inolvidable / An Unforgettable Trip

Sacred nature, like Ganges and banyan tree:

In a year of torrential rains, the village of Baliganj, at the mouth of the river Ganges ${ }^{1}$, was completely inundated.

(Footnote) ${ }^{1}$ Sacred river of India which flows into the Bay of Bengal, in the northeast of the country.

The sarpanch is seated under a banyan tree ${ }^{4}$ on a cemented platform constructed around its base.

(Footnote) ${ }^{4}$ Holy tree of India with aerial roots.

Una decisión inteligente / A Smart Decision

According to Saran (1988), it is also appropriate to observe more sociological approaches when constructing knowledge in different cultures and, besides modernity or universality, to place value also on aspects like the traditional world and religion. Marrying daughters and dowries is an example of the former in the first tale:

Rohan, on the other hand, understood his father. He knew that his father had many problems. First, he had to save money for his sister's dowry ${ }^{2}$.

(Footnote) ${ }^{2}$ When a woman gets married in India, her family hands her over to the husband's family together with a dowry that has been previously agreed between both families. Sometimes, the dowry determines whether a woman is accepted for marriage or not. For this reason, parents to female children save as much as they can in order to increase the possibilities to marry their daughters to a good husband or family. Once married, women belong to their husband's family.

El sueño redondo / The Round Dream 
Parallelism among cultures can also be established. A clear example is found in a reference to black cats and superstitions:

Then, when Sita and I were returning home, we saw something unusual. A black cat ${ }^{1}$ crossed the way of a child who started playing with the animal.

(Footnote) ${ }^{1}$ India is a very superstitious country, where black cats also bring bad luck. If you see one, you have to walk ten steps backwards.

La comprensión / The Realisation

As to religion, terms related to Hinduism are used, alongside their respective footnotes, in different tales throughout the collection:

Auspicious day: (Footnote) According to the Hindu calendar, certain days of the year bring good luck. Therefore, they are chosen for celebrations or to start or inaugurate something. Full moon days are an example.

Pooja: (Footnote) A word used in India to refer to a ceremony where Hindus pray to their gods. Normally, fruits and flowers are offered to god. Pooja is also done to start something new and bring good luck.

Diwali: (Footnote) Festival celebrated almost all over India around the months of October and November. It is the most important festival for Hindus. It celebrates the victory of Rama over Ravana, who had kidnapped the former's wife.

According to the 2011 census $^{13}$, religious composition in India is presented as follows: 80.5\% Hindus; 13.4\% Muslims; 2.3\% Christians; 1.9\% Sikhs; 0.8\% Buddhists; 0.4\% Jains; 0.6\% follow other religions and persuasions, and $0.1 \%$ do not state any religion. Among our students, 16 were Hindus (80\%), 2 Catholics (10\%), 1 Parsi (5\%) and 1 agnostic born Catholic (5\%).

No references to other religions rather than Hinduism are observed in the tales. Whether these references were chosen on a religion basis or on a tradition one would be a matter of further discussion. We find only one case that could apply to any religion:

I am overcome with sadness on hearing of the suffering that has been caused by this act of God ${ }^{7}$.

(Footnote) ${ }^{7}$ In India, natural calamities are referred to as an act of God.

From the linguistic point of view, the collection of bilingual tales will allow learners of English as Foreign Language to read narratives written far from their demographic and cultural proximities. Furthermore, their audio versions, will allow them to get exposed to the nuisances, intonation and pronunciation of English in India, a language with official status at national level, alongside with Hindi and 22 other languages from the different States ${ }^{14}$. Knowledge is, therefore, 
intended to be built upon linguistic variation grounds, added to cultural ones, by exposing readers and learners of English to the existence of different Englishes (Galloway \& Rose, 2015). If with different languages come different nuances unique to that language and our understanding of culture will always be restricted by the number of languages we know (Pattanaik, 2017, p. 95), work published for this research aims at being empirical evidence that the same can apply to the fact of being exposed to geographical variations of the same language.

\section{Conclusions and implications}

We can conclude that this exercise of writing stories with learners of SFL at the University of Mumbai met the three objectives established beforehand:

Firstly, its starting point was both the learners' academic and social realities. As a process of sociocultural reflection, students were aware of being involved not only in their own learning, but also in their communities. Their stories, far more than being a mere linguistic phenomenon or a form of entertainment, become a sum and a projection of historical and sociological factors, as well as of values that explain and reaffirm ways of life, organisation of their society and their way of perceiving the world around them.

Secondly, the whole project and its publication entailed a joint development of linguistic, communicative and intercultural skills among participants. Through their stories, they shared ideas, ways of reasoning and behaviours that characterise their culture and that, at the same time, differentiate them from other cultures.

Lastly, regarding the published book, it serves as evidence of learning. Moreover, within the TALIS framework, in addition to presenting itself as material for reading and learning languages, it is a valuable didactic tool to work interculturality in the classroom, adapted to different contexts and learning situations.

Further research in work being conducted with the published tales will provide a better insight into aspects like how different literacies are developed by foreign readers, how stories are decoded in different cultural systems, and how minds are opened to other cultural interpretations, like Ruiz-Cecilia pointed in his pilot study (Ruiz-Cecilia, 2012, pp. 227-238). Analysis, on a second stage, of the real impact of the intercultural work on different readers will give us a comprehensive view of an integral process that aims at being multidirectional.

$1 \quad$ www.proyectotalis.com. 
2 Programme funded by Spain's Ministry of Foreign Affairs and Cooperation (MAEC) and the Spanish Agency for International Cooperation and Development (AECID) to teach Spanish in foreign universities.

3 According to the Instituto Cervantes reports for the academic year 2016-2017, its language and culture centres in Manila, New Delhi and Pekin were the three top most in terms of teaching hours. Related to this, Instituto Cervantes in New Delhi grew by $16 \%$ in comparison to the previous year. Enrolment figures increased from 4,344 to 5,292. Information is available from Memoria del Instituto Cervantes 2016-2017, Madrid, 2017, http://www.cervantes.es/sobre instituto cervantes/memoria 2016 2017.htm.

$4 \quad$ Available in the following tab of the subject blog: https://chutneyconsalsa.blogspot.com.es/p/cuentos 1.html.

$5 \quad$ Festival celebrated almost all over India around the months of October and November. It is the most important festival for Hindus. It celebrates the victory of Rama over Ravana, who had kidnapped the former's wife. (Footnote from the tale An Enlightening Nest).

6 According to the Hindu calendar, certain days of the year bring good luck. Therefore, they are chosen for celebrations or to start or inaugurate something. Full moon days are an example. (Footnote from the tale ...And the Forest Was Saved).

$7 \quad$ A word used in India to refer to a ceremony where Hindus pray to their gods. Normally, fruits and flowers are offered to god. Pooja is also done to start something new and bring good luck. (Footnote from the tale ...And the Forest Was Saved).

8 In India, natural calamities are referred to as an act of God. (Footnote from the tale $A$ Smart Decision).

9 Piece of long cloth that men wear, instead of pants, which is tied up around the waist. (Footnote from the tale $A$ Smart Decision).

10 Reunion where villagers talk about their problems. It is like a court for the villagers. (Footnote from the tale The Round Dream).

11 Head of the village. He finds solutions to the problems of the villagers. (Footnote from the tale Education is a Need).

12

http://mmedia.uv.es/buildhtml?user=peloplu\&name=Universidad.mp4\&path=/cream/2016 2017 proyectos/rmd TALI $\mathrm{S} /$

$\overline{13}$ http://censusindia.gov.in/Census Data 2001/India at glance/religion.aspx.

14 http://censusindia.gov.in/2011Census/C-16 25062018 NEW.pdf.

\section{References}

Byran, M., \& Fleming, M. (2009). Perspectivas interculturales en el aprendizaje de idiomas. Madrid: Edinumen.

Council of Europe (2001). Common European framework of reference for languages: Learning, teaching, assessment. Cambridge: Cambridge University Press.

Council of Europe (2018). Common European framework of reference for languages: Learning, teaching, assessment. Companion volume with new descriptors. Strasbourg.

Galloway, N., \& Rose, H. (2015). Introducing global Englishes. Abingdon, Oxon: Routledge. DOI: https://doi.org/10.4324/9781315734347

Guillén Díaz, C. (2016). Los contenidos culturales. In J. Sánchez Lobato, I. Santos Gargallo, \& J. S. Gargallo (Ed.), Vademécum para la formación de profesores: Enseñar español como segunda lengua (L2)/lengua extranjera (LE) (pp. 227-241). Madrid: SGEL.

Gutiérrez Rivilla, R. (2016). Directrices del Consejo de Europa: el Marco común europeo de referencia para las lenguas: aprendizaje, enseñanza, evaluación (2002). In J. Sánchez 
Lobato, I. Santos Gargallo, \& J. S. Gargallo (Ed.), Vademécum para la formación de profesores: Enseñar español como segunda lengua (L2)/lengua extranjera (LE) (pp. 11-33). Madrid: SGEL.

Haba Osca, J., Alcantud-Díaz, M., \& Peredo Hernández, J. (2015). Taller de escritura creativa para el desarrollo de la competencia literaria en Brasil. Didáctica. Lengua y Literatura, 27, $97-$ 110. DOI: https://doi.org/10.5209/rev_dida.2015.v27.50868

Hall, B. J. (2005). Among cultures: The challenge of communication. Belmont, CA: Thomson Wadsworth.

Instituto Cervantes (2017). Memoria del Instituto Cervantes 2016-2017. Retrieved from http://www.cervantes.es/sobre instituto_cervantes/memoria 2016 2017.htm.

Jian, L. (2013). Transferencia linguistica y cultural en el aprendizaje de español de los hablantes chinos. Presente y futuro del hispanismo en el Oriente (pp. 202-220). SinoELE monográficos.

Jin, L., \& Cortazzi, M. (2009). La cultura que aporta el alumno: ¿puente u obstáculo? In M. Byram, \& M. Fleming, Perspectivas interculturales en el aprendizaje de idiomas (pp. 104-125). Madrid: Edinumen.

Neelakantan, K. (2012). Studies in Indology. Chennai: Adyar Library and Research Centre.

Oranje, J., \& Smith, L. F. (2017). Language teacher cognitions and intercultural language teaching: The New Zealand Perspective. Language Teaching Research, 1-20. DOI: https://doi.org/10.1177/1362168817691319

Pattanaik, D. (2017). Culture: 50 insights from mythology. Noida: Harper Collins.

Porto, M., Houghton, S. A., \& Byram, M. (2017). Intercultural citizenship in the (foreign) language classroom. Language Teaching Research, 1-15. DOI: https://doi.org/10.1177/1362168817718580

Riutort Cánovas, A., \& Pérez Villafañe, E. (2013). Enseñanza del español como lengua extranjera en la República Popular de China. Adaptación al contexto y superación de las metodologías. Presente y futuro del hispanismo en el Oriente (pp. 238-252). SinoELE monográficos.

Rodrigo-Mateu, A. (2017). Mucho más que ríos de vida y fuertes de leyenda... Cuentos de India / Much more than rivers of life and legendary forts... Tales from India. Valencia: MónSul.

Ruiz-Cecilia, R. (2012). Narrowing cultural boundaries in the EFL classroom: fairy tales from India. RESLA, 25, 225-243. 
Saran, A. K. (1998). Sociology of Knowledge and Traditional Thought. Varanasi: Central Institute of Higher Tibetan Studies.

Trujillo Sáez, F. (2002). Towards interculturality through language teaching: argumentative discourse. CAUCE, Revista de Filología y su Didáctica(25), 103-109.

Vevaina, C. (n.d.). Coomi Vevaina. Retrieved from http://coomivevaina.com/courses/2.

\begin{abstract}
Author's information
Amparo Rodrigo-Mateu is teacher in Spanish as a foreign language with experience in the UK, Germany, Austria, Morocco, USA and India. She is a PhD student at University of Valencia, where she is also member of the TALIS Project $^{14}$ (Teaching and Acquisition of Solidarity and Intercultural Competences through Languages and Literature) research group. Her research focuses on language acquisition and intercultural competences.

Amparo Rodrigo-Mateu es profesora de español como lengua extranjera, con experiencia en Reino Unido, Alemania Austria, Marruecos, Estados Unidos e India. Es estudiante de doctorado en la Universidad de Valencia, donde también forma parte del grupo de investigación Proyecto TALIS ${ }^{1}$ (Enseñanza y Adquisición de Competencias Solidarias e Interculturales a través de las Lenguas y la Literatura). Su investigación se centra en aprendizaje de lenguas y competencias interculturales.

Amparo Rodrigo-Mateu és professora d'espanyol com a llengua estrangera, amb experiència al Regne Unit, a Alemanya, a Àustria, al Marroc, als Estats Units i a l'Índia. És estudiant de doctorat a la Universitat de València, on també forma part del grup d'investigació Projecte TALIS ${ }^{1}$ (Ensenyament i Adquisició de Competències Solidàries $i$ Interculturals a través de les Llengües i de la Literatura). La seua investigació se centra en aprenentatge de llengües $i$ competències interculturals.
\end{abstract}

E-mail: amroma@alumni.uv.es

To cite this article:

Rodrigo-Mateu, A. (2018). Language, culture and interculturality through narratives with learners of Spanish as a foreign language. Bellaterra Journal of Teaching \& Learning Language \& Literature, 11(4), 41-58. DOI: https://doi.org/10.5565/rev/jtl3.761 